\title{
SEMANTIC MOTIVATION OF THE TERMINOLOGIZED LEXIS IN THE FIELD OF DIGITAL TECHNOLOGIES
}

\author{
Vilija Celiešienè, Saulutẻ Juzelènienè \\ Kaunas University of Technology, Lithuania \\ E-mail: vilija.celiesiene@ktu.lt, saulute.juzeleniene@ktu.lt
}

\begin{abstract}
Digital technologies are changing people's lives, the way we communicate, learn and work. Modern language teaching technologies are changing the ways we learn languages as well. On the other hand, the language itself is changing as technology advances. The aim of this article is to reveal semantic motivation of terminologized Lithuanian and English computer lexis. The present research, focusing on semantic motivation of IT terms, is also aimed at identifying similarities and differences between the semantic models of the words in both contacting languages, and revealing the factors that determine the choice of foreign sememes. In addition, the article sheds some light on semantic relations of IT terms, as well as on tendencies in the shifts of meanings of specific $L T$ and EN common language words, related to the process of terminologization. It has been established that the majority of the analysed words that have entered the Lithuanian IT vocabulary as a result of terminization and transterminization processes can be considered semantic loan-translations, having acquired new meanings from foreign (usually English) words, and based on 'borrowed' motivation. Nonetheless, many such words can also be substantiated in Lithuanian, for their terminological meanings can be explained by central, nonterminological meanings. Thus, in the majority of cases, close associations between central meanings of specific English and Lithuanian words have stimulated the development of new terminological meanings related to information technologies. By contrast, only a relatively small number of the analysed Lithuanian terms can be considered semantic formations, having acquired their terminological meanings in the process of turning Lithuanian common language words into terms.
\end{abstract}

Key words: digital/IT terminology, semantic motivation, semantic loan-translations, terminologization

\section{INTRODUCTION}

The aim of this article is to reveal semantic motivation of terminologized Lithuanian and English computer lexis. The present research, focusing on semantic motivation of IT terms, is also aimed at identifying similarities and differences between the semantic models of the words in both contacting languages, and revealing the factors that determine the choice of foreign sememes. In addition, the article sheds some light on semantic relations of IT terms, as well as on tendencies in the shifts of meanings of specific LT and EN common language words, related to the process of terminologization.

Submitted January $9^{\text {th }}, 2020$, accepted for publication February $14^{\text {th }}, 2020$ 
New words are constantly being created and recreated, especially when it comes to a huge amount of new computer related realities. On the other hand, only by understanding the meaning of these terms is it possible to make professional use of these technologies. It has been noticed that most Lithuanian terms in computer science have semantic values of the English language (M. Paura, 2014; A. Kaulakienè, 2001, 2008, etc.). The choice of such foreign-language sememes is determined by the similarities and differences between the semantic models of Lithuanian and English words. Whether the new term, which is based on borrowed motivation will come into play in language will depend on how well it is motivated in the Lithuanian language. It is also important, how well its terminological meaning is based on the former non-terminological meaning.

Motivation is usually defined as a psychological feature and condition that determines the activity and directionality of a person in a particular situation (Albrechto 2005: 110). It triggers a particular behaviour, actions, and particular activities, and is caused by a variety of motives. In linguistics, motivation is understood as the semantic-structural feature of a word that allows one to perceive the relation between its meaning and its formal composition (Jakaitiene 2010: 26). A 'motivated' word means the word that can be explained and is well-founded, for instance, branch, when used meaning department, it is motivated by the meaning of the word branch - tree brunch. The attribute 'branchness' becomes important in the motivation of the 'department' concept. The internal form of the word and the motivating sign reflect the attitude of a person towards the object being named. By revealing a motivating attribute, it is possible to explain how a phenomenon or object receives one or another name on the basis of certain attributes and how this complexity of factors affects human subconsciousness.

Terminologists consider motivation to be one of the basic attributes of a term. It is easier to remember a motivated term and to associate it with other terms, but this requirement, according to J. Gaivenyte (2000: 19) is to be regarded as additional only, since the positioning of the term in the system can be determined from its definition, and the essential characteristic is not always chosen as a motivating factor. Motivation can also be determined by random associations. Though semantics and motivation of the term are important, it is also important to remember that a term is rather a matter of agreement. The term is a specific unit of lexis, and its motivation has certain peculiarities.

Motivation of terms as a linguistic aspect has not received assiduous attention of Lithuanian linguists so far. J. Gaivenytė (2000: 19-25), having analysed Lithuanian compound nominative terms related to the field of physics and their English equivalents, noticed that Lithuanians had mostly adopted the concepts and terms related to the field of physics, because only about half of the terms could be considered of the Lithuanian origin. A. Gritenienè (2006) studied motivation of plant names and focused on tendencies of coining the names, usage, dissemination of names, novelty, and the origin of certain borrowed terms. J. Lubienè (2008) investigated names of funguses as one-word terms, the motivation of which, as it was found out, is determined by external and internal qualities of funguses. The study of geographical terms coined by J. A. Pabrèža, carried out by R. Gedrimas (2003), includes a section on analysis of semantic formations. E. Jakaitienè (1988), K. Gaivenis (2002), and S. Keinys (2005) have also explored aspects of semantic formations in their works.

The semantics and motivation of informatics and computer terminology have been analysed more thoroughly in publications by A. Kaulakiene $(2001,2008)$. The researcher has investigated and evaluated the spread of semantic formations and loan-translations in the basic computer terminology, paying more attention to the development of the lexical 
items such as computer, hardware, software, microsystem, etc. The semantic field consisting of the words that describe the concept of computer virus was investigated in the dissertation by M. Paura (2014). In some of his works, M. Paura (2008) has also noticed the tendency to turn common Lithuanian words into terms. In his opinion, this tendency could be regarded as an example of attributing new meanings to the existing Lithuanian words (Paura 2008). V. Celiešienè (2016) has focused on the extent to which this tendency is generally typical of the Lithuanian terminology related to the field of information technologies and has noticed that shifts in the meanings of specific common Lithuanian words can be considered factors driving the creation of new computer terms.

Methods of description, comparison, and oppositions have been applied in this study. The concept properties are differentiated with regard to logical linguistic concept comparative methods according to the definitions provided in dictionaries.

The sample of the research consists of simple Lithuanian terms that have originated in the processes of terminologization and transterminologization, included in the Encyclopaedic Dictionary of Computer Terms (EKŽ), and the corresponding English words in EuroTermBank (ETB) and Encyclopedia. The Computer Language Company Inc. (PCmagE). The online resource "The Encyclopaedic Dictionary of Computer Terms" (EKŽ) has been selected as the primary source of terms for analysis. This resource includes about 4.6 thousand entries. The current research has focused on simple terms (one-word lexical units, nouns) included in EKZ̆; the resource contains 917 such lexical units. It has been found that 58 percent of simple terms included in this Dictionary are of the Lithuanian origin, and 16 percent of the units out of the mentioned percentage can be considered semantic loantranslations. These reliable sources provide comprehensive definitions of terms. The study focuses on simple semantic formations and semantic loan-translations. These units are common language words that have been turned into IT terms or have been adopted from other subject areas. According to M. Paura (2008), such words are only seemingly simple, as in the field of information technologies they are provided with definitions, which separates them from the commonly used linguistic items and turns them into units of specialized lexis.

\section{THEORETICAL BACKGROUND}

Each language consists of motivated and unmotivated words. The meaning of unmotivated words is primary, thus it cannot be explained by other words, whereas the meaning of a motivated word can be easily explained by comparing it to the meanings of related words (Griteniene 2006: 24). Thus, motivation is one of the most important factors influencing the information carried by a word. Motivated and unmotivated distribution of words in a language is a semantic universality. It can be stated that there is no such a language that would consist of motivated words only and would not include any metaphors, etc. According to S. Ullmann "[t]hree motivation types can be applied in English and many other languages: phonetic, morphological, and semantic. A phonetic word similarity to natural sounds related to a signifier is considered phonetic motivation; morphological (or formation) motivation is based on the choice of the sound expression of the word for its content; semantic - the emergence of a new (metaphorical or metonymic) meaning of the word used figuratively. Morphological and semantic motivation should be considered "relative". In the first case, motivated words may contain non-substantiated morphemes; 
in the second case, phraseological units including certain words can be motivated, although literal meanings of the words are conditioned" (Ullmann 1970: 254-255).

Many terminologists (Gajda 1990, Kaulakienė 2014, Gaivenytė 2000, etc.) regard all terminologized words that have been turned into terms due to semantic transfer as motivated ones. The third type of motivation is called semantic motivation. It is based on the coexistence of direct and figurative meanings of the same word within the same synchronous system. Mouth continues to denote a part of the human face, and at the same time it can metaphorically apply to any opening or outlet: the mouth of a river, of a cave, of a furnace. Jacket is a short coat and also a protective cover for a book, a phonograph record or an electric wire. Ermine is not only the name of a small animal, but also of its fur, and the office and rank of an English judge because in England ermine was worn by judges in court. In their direct meaning neither mouth nor ermine is motivated.

Most words used in any language usually change semantically. "The meaning of the word varies due to certain ways of communication (metaphors, metonymy, etc.) that allow the already existing potential of utterances to be used for new purposes" (Fritz 1998: 42). The meanings of words are constantly expanding, narrowing, or being transferred from one conceptual sphere to another, or acquire certain stylistic nuances (Rudaitienè 2014: 114). Under conditions of technological progress, the language constantly eliminates new words to name new concepts, most of which are terms in one or another field. As science and technology are developing rapidly, terminologists may sometimes struggle to coin new terms for naming new concepts fast. Creation of new terms is a complex process, thus, terminization becomes one of the main terminology sources: commonly used words are transferred to a specific scientific field and become terms, or some already existing terms are transferred from one field to another. According to S. Keinys (2005: 231), this practice is convenient, and such terms can be easily used for creation of new terms. This also indicates that creation of neologisms is not always necessary if common language words can be taken as terms.

Therefore, terminization is a process in which the common language words are turned into terms, acquiring terminological meaning. While terminologizing ready-made words, it is important to adhere to a specific principle: the terminological meaning cannot be in conflict with the lexical meaning of the word. Failure to stick to this principle leads to formation of misleading terms (Gaivenis 2002: 51). Terminization is usually related to semantic modification and definition of a word. Generally, terms are created by extending or narrowing a specific meaning of the word, less often - by means of metaphorical expansion or meaning correction. Such words in terminology refer to concepts of specific fields, and definitions reveal the content of the concepts.

Science integration and synthesis have stimulated the adoption of terms from one domain to another (Keinys 2005: 232). A term from one subject area can often be transferred to another by transterminisation. For example, šaka in LT (branch in EN) in the wood industry is an outgrowth of a tree trunk, a separate component of its branched stem; in communication, the "network link or the line connecting two adjacent nodes and without intermediate nodes" (Term Bank of the Republic of Lithuania, TB). If the term has been based on the common language word, without knowing its etymology, it is often difficult to determine whether it has emerged by the way of terminization or transterminization (i.e., by secondary or even tertiary nomination) (Celiešienè 2016: 47).

Terminological nomination is secondary to general nomination (Gaivenyte் 2000: 19). According to Paura (2014: 30), secondary nomination occurs when common language 
words are given special meanings in a particular field of science by directly terminologizing them. Tertiary nomination occurs when terms are transferred to a specific field from other subject areas by internal borrowing (transterminization).

Common language words that have been turned into terms and have acquired additional meanings on the basis of specific meanings can be regarded as semantic formations. The words which acquire new meanings are referred to as semantic neologisms in linguistics. A new meaning of the newly made term shares common semes with the meaning of the common word, which have motivated the new term" meaning (Gedrimas 2003: 122). In this case, according to Jakaitiene (1988: 92-93), both the source of formation and the result of formation coincide formally, i.e., there is no formal difference between the "source, underlying? word and the newly formed word. In other words, the result of this process is acquisition of a new meaning by the same word, for example:

(1) a. sememe leaf 1: one of the flat, usually green parts of a plant that are joined at one end to;

b. the stem or branch (The Cambridge English Dictionary, CED);

c. sememe leaf 2: a thin sheet of paper (CED);

d. sememe leaf 3: an extra part of a table that can be folded away when not being used (CED).

It should be noted that the term transferred to a new domain acquires a newly defined meaning and in each subject field it exists as a separate semantic unit. Synchronically, the first sememe is motivating, and the rest (leaf 2, leaf 3) are motivated. The motivated term is peculiar, for it combines the motivating and motivated concepts. The relationship between such sememes can be explained by semantic motivation, which is determined either by the actual similarity of the objects named, or by associations created by imagination, or by a logical connection between the named objects (Jakaitienè 1988: 92-93).

Therefore, semantic motivation is related to the extension of the central meaning of the word, permitting to account for a number of minor meanings. It is important to mention that in the semantic structure, the motivating sememe is semantically independent because its name is not related to the name of another concept. Meanwhile, the motivated sememes are semantically non-autonomous, since they can be explained by the meaning of the first sememe. For example, the computer term virus, meaning software used to infect a computer (PCmagE), can be easily explained by the medical term virus (EOD), but the reverse is probably unrealistic.

In Lejczyk's (1998) view, as soon as a lexical unit starts functioning as a term, from a terminological point of view, it is important to observe if this secondary terminological meaning can be explained by the primary, non-terminological meaning; it is also important to establish the position of the term within the terminological system. Many terminologists consider the words that have been turned into terms by semantic transfer, to be motivated ones (Danilenko 1977: 63), for example:

(2) kernel: the part of a nut that is inside the shell and can be eaten (CED) [motivating sememe] - the core of the layered architecture that manages the most basic operations of the operating system and the computer processor (ETB) [motivated sememe].

In general, it is difficult to determine which term is trans-semanticized, especially when foreign language sememes are expressed by lexemes in a native language. This is when semantic loan-translations appear. The choice of foreign language sememes is determined by similarities and differences between the semantic models of the words in the contacting 
languages. The result of the "semantic encounter" is a new meaning of the word, derived from another language; at the same time the structure and pronunciation of this newly developed word are "native" (Kaulakienè 2014: 171), for example: the computer term mouse (English "mouse", French souris "mouse", Lithuanian pele "mouse", Russian mblub "mouse"). "Thus, these semantic loan-translations are based on the meaning (semantics) of the source word. Linguists have also referred to them as to "hidden borrowings" in their works" (e.g., Keinys 2005: 245).

A. Kaulakiene (2014) explains the spread of semantic loan-translations in terminology by several reasons: "firstly, terminology constantly changes, and new concepts are emerging. If the use of semantic loan-translations were not considered appropriate, we would have to coin a lot of new linguistic units. Secondly, semantic loan-translations help to systematise separate terminology systems. Thirdly, the majority of semantic loantranslations is the source of new formations of a different nature or the basis of compound terms" (Kaulakiene, 2014: 171).

In addition, it should be emphasized that the meaning is only borrowed if the motivating sememe of the source language and the motivated sememe in the target language have a common semantic element. According to Jakaitiene (2010: 128), the motivating meaning is usually the main meaning of the word, which determines the appearance of additional meanings. For example, the primary meaning of the word trap (a device or enclosure designed to catch and hold animals, usually by allowing entry but not exit or by catching a part of the body; EOD), influenced its secondary meaning: a container or device used to collect something, or a place where something collects (EOD).

Because of the universal pattern of thinking and similar experience, many cases of meaning transfer are similar in different languages. The aforementioned semantic tendencies are a universal phenomenon, and, in order to confirm that certain development of meanings is really possible, analogies are sought in modern languages. The aim of this study is to define similarities and differences between semantic models of the words of the contacting languages (Lithuanian and English), influencing the choice of foreign sememes, and to reveal semantic relations of IT terms.

\section{RESUlTS OF THE ANALYSIS AND DISCUSSION}

\subsection{Terminization of the common language words in computer lexis}

Analysis of the terms chosen for the research shows that both Lithuanian and English computer terminology includes a number of simple terms that have evolved from common language words as a result of shift in the meanings of the common words:

(3) aklaviete 'deadlock', apgaule 'hoax', gija 'thread', kloste 'fold', kauke 'mask', kirminas 'worm', krepšys 'bag', langas 'window', mazgas 'node', medis 'tree', netiesa 'false', lapas 'leaf', šaknis 'root', pagalba 'help', raktas 'key', paveldejimas 'inheritance', pelè 'mouse', svečias 'guest', šešèlis 'shadow', žingsnis 'step', žvaigžduté 'asterisk', etc.

Furthermore, the researchers have determined that some Lithuanian computer terms have English equivalents that are not common English words turned into terms:

(4) Lithuanian term kilpele 'loop' / English terms at, commercial at;

(5) Lithuanian term papildinys 'addition' English terms plug-in, plugin;

(6) Lithuanian term asele 'handle' English term tab. 
It seems likely that a large part of computer terminology has originated as a result of tertiary nomination (transterminization) and not secondary nomination (terminization). Most of the analysed terminologized common language words with acquired new meanings in the computer science are also used in other scientific fields as terms:

(7) Lithuanian term šaknis / English term root:

(7a) biology: the part of a plant which attaches it to the ground or to a support, typically underground, conveying water and nourishment to the rest of the plant via numerous branches and fibres (OED);

(7b) linguistics: a morpheme, not necessarily surviving as a word in itself, from which words have been made by the addition of prefixes or suffixes or by other modification (OED);

(7c) music: the fundamental note of a chord (OED);

(7d) mathematics: a number or quantity that when multiplied by itself, typically a specified number of times, gives a specified number or quantity (OED);

(7e) computing: a user account with full and unrestricted access to a system (OED).

(8) Lithuanian term mazgas / English term node:

(8a) technical: a point in a network or diagram at which lines or pathways intersect or branch $(\mathrm{OED})$;

(8b) physics and mathematics: a point at which the amplitude of vibration in a standing wave system is zero (OED);

(8c) astronomy: either of the two points at which a planet's orbit intersects the plane of the ecliptic or the celestial equator (OED);

(8d) botany: the part of a plant stem from which one or more leaves emerge, often forming a slight swelling (OED);

(8e) anatomy: a lymph node or other structure consisting of a small mass of differentiated tissue (OED);

(8f) computing: in a communications system, a node is a network junction or connection point. Every terminal, computer, hub and switch is a node (PCmagE).

It has been noticed that the following Lithuanian and English common language words have been terminologized in more than one subject area:

(9) a. Lithuanian term kauke / English term mask;

b. Lithuanian term krepšys / English term bag;

c. Lithuanian term šaknis / English term root;

d. Lithuanian term mazgas / English term node;

e. Lithuanian term lapas / English term leaf;

f. Lithuanian term medis / English term tree;

g. Lithuanian term raktas / English term key;

h. Lithuanian term židinys / English term focus;

i. Lithuanian term branduolys / English term kernel;

j. Lithuanian term žingsnis / English term step;

k. Lithuanian term tinklas / English term network etc.

The cases involving computer terms that entered the computer terminology in both languages as a result of secondary nomination are much less common. For instance, the common language word nevykèlis (Lithuanian) / lamer (English), which is defined as stupid, inept, or dull person (OED), has been turned into a computer term as a result of meaning narrowing: technophobic person or neophyte to computers and technology, as viewed by the technically competent who have little empathy for the novice (PCmagE). 
The examples provided below are computer terms that evolved from common words as a result of secondary nomination:

(10) Lithuanian term ịsilaužèlis / English term intruder: An attacker that gains, or tries to gain, unauthorized access to a system (PCmagE);

(11) Lithuanian term krūva / English term heap: In programming, it refers to a common pool of memory that is available to the program. The management of the heap is either done by the applications themselves, allocating and deallocating memory as required, or by the operating system or other system program (PCmagE);

(12) Lithuanian term podèlis / English term cache: An auxiliary memory from which high-speed retrieval is possible: [as modifier] 'typical cache sizes range from $64 \mathrm{~K}$ to $256 K^{\prime}(\mathrm{OED})$;

(13) Lithuanian term patikèjimas / English term trust: In network directories, a trust is the passing of the rights of one group to another (PCmagE), etc.

In the analysed sample, the authors of this study have identified several words that have entered Lithuanian computer terminology via tertiary nomination (transterminization) and the English terminology - via secondary nomination, for instance: while TB includes 3 meanings of the Lithuanian term apgaule 'hoax', the same English word hoax is only used as a term in the IT area. Other similar examples include the following: Lithuanian term paveldejimas (English inheritance) - 5 definitions in TB; Lithuanian šiukšlès (English garbage) - 4 definitions in TB; Lithuanian kelias (English path) - 12 definitions in TB.

The results of the study allow the researchers to make an assumption that the tendency to adopt terminology from one scientific area and to introduce it into other scientific areas (the method of transterminization) is characteristic of both English and Lithuanian. Such adopted terms acquire new specific meanings and become new separate semantic units.

\subsection{Semantic motivation of digital terms}

Main Lithuanian simple terms, belonging to the field of information technologies, analysed in this section, may be regarded as common language words that have been turned into terms in the process of terminologization. When comparing them with the English words denoting the same concepts, it can be noticed that some of the concepts and their definitions have likely been borrowed from English as well, for as we know, the USA had been a pioneer in development of computer technology as well as coining computer terminology. Therefore, many Lithuanian terms related to the field of information technologies can be considered semantic loan-translations.

Further on we provide some examples of Lithuanian semantic loan-translations and their English equivalents:

(14) LT word Aklaviete (en.'deadlock') - general meaning: Situation with no exit, feeling stuck (DLKŽ). Definition of term - In operating systems and database applications, a situation in which two or more processes cannot continue because each process is waiting for resources to be freed by the continuation of the other process (ETB); EN word Deadlock - general meaning: A situation, typically one involving opposing parties, in which no progress can be made (OED);

(15) Kirminas (en. 'worm') - general meaning: an elongated creeping or swimming invertebrate (DLKŽ). Definition of term - Self-propagating malicious code that can automatically distribute itself from one computer to another through network connections 
(ETB); EN word Worm - general meaning: Any of a number of creeping or burrowing invertebrate animals with long, slender soft bodies and no limbs (OED);

(16) Langas (en. 'window') - general meaning: a space in the wall which has glass in it so that light can come in (DLKŽ). Definition of term - a viewing area on screen that contains a surrounding frame (border). It is used to separate parts of an application from each other and to separate one application from another (PCmagE). EN word Window general meaning: An opening in the wall or roof of a building or vehicle, fitted with glass in a frame to admit light or air and allow people to see out (OED);

(17) Lapas (en. 'leaf') - general meaning: a flattened structure attached to a stem of a plant, the life-giving part of the plant body (DLKŽ). Definition of term - in database management, the last node of a tree (PCmagE). EN word Leaf - general meaning: a flattened structure of a higher plant, typically green and blade-like, that is attached to a stem directly or via a stalk (OED).

As it can be seen from the examples, though translation loanwords are based on 'borrowed' motivation, in many cases they are sufficiently motivated in the Lithuanian language as well, for their terminological meanings can be explained by their nonterminological meanings. As A. Kaulakienè (2014: 233) has noticed, one can identify specific points of semantic intersection between semantically motivated words of contacting languages: central meanings of such words are close. For example, the concept of inheritance in Lithuanian, expressed by words palikimas (English legacy, heritage, devise) and paveldejimas (English inheritance, heredity, succession) is close to the meaning of inheritance in English. The observation that such "intersection points" exist (i. e., the central meanings are close), enabled terminologists to coin a new computer term inheritance, describing a computer-related concept:

(18) Lithuanian paveldejimas 'inheritance' - nauju objektinio programavimo klasiu kūrimas iš turimu; nauja klasé paveldi visas turimos klasés savybes ir gali turèti savu (EKŽ): 'a new class inherits all the features from the available class and can include its own features';

(19) cf. English inheritance - In object technology, the ability of a class of objects to inherit properties from a higher class (PCmagE).

Another example is the Lithuanian word svečias (English guest), with the central meaning draugiškas namu lankytojas arba pašalinis asmuo, pakviestas $i$ koki posédĭ, susirinkima (DLKŽ): 'a friendly guest visiting the house or an outsider invited to the meeting'. It is close to the central meaning of the English word guest: a person who is invited to visit someone's home or attend a particular social event (OED). The observation that the central meanings of the words in both languages are close enabled IT specialists and terminologists to coin a new computer term svečias 'guest':

(20) Lithuanian svečias 'guest' - neturintis paskyros (neužsiregistravęs) kompiuterinès sistemos naudotojas, kuris naudojasi tam tikromis svečio teisèmis (EKŽ): 'an unregistered user of the computer system who does not have a personal account, but is given specific guest rights';

(21) cf. English guest - a person who logs into a network or service that does not have a user account. Guests are given a default set of privileges until they officially register with the service (ETB).

Just a few units of simple computer terms with new meanings derived from Lithuanian have been identified in Encyclopaedic Dictionary of Computer Terms (EKŽ; 
the bilingual LT-EN, EN-LT online dictionary). These units can most likely be considered Lithuanian semantic formations, for example:

(22) Lithuanian term assele 'handle' (English term tab) - a prominent part of the card which opens the card when clicked (EKŽ);

(23) Lithuanian term kilpelè/ ženklas eta 'loop' (English terms at, commercial at) the sign @, used to separate the email address of the subscriber's name from the rest of the address. Code: 64 (ASCII, decimal), 40 (ASCII, hexadecimal) (EKŽ);

(24) Lithuanian term papildinys 'addition' (English term plug-in, plugin) - an additional component embedded in the program, a computer or its gadget, which extends its capability (EKŽ);

(25) Lithuanian term svetaine 'parlour' (English term website) - a set of web pages on a common topic, associated with a specific entity, or providing information on other related matters (EKŽ);

(26) Lithuanian term taškas 'dot' (English term pixel) - the smallest element in pixel graphics (EKŽ), etc.

The analysis of selected examples has revealed that the majority of Lithuanian computer terms can be considered semantic loan-translations, rendering which requires projecting the semantics of foreign units onto Lithuanian words. Therefore, it can be stated that a major part of Lithuanian computer terms has been adopted from English and has not been created by Lithuanians.

\section{CONCLUSION}

Semantic motivation is related to the extension of the central meaning of the word, permitting it to include new referents (objects or ideas to which the word refers). It has been established that the meaning is only borrowed if the motivating sememe of the source language and the motivated sememe in the target language have a common semantic element. In the majority of cases, the central meaning of the word is the motivating meaning, determining the development of coexisting meanings.

Many cases of meaning transfer are similar in different languages due to universal patterns of thinking and similar experience. The semantic tendencies described in this article are considered a universal phenomenon, and, in order to confirm that certain development of meanings is realistic, analogies are sought in modern languages. The aim of the present study has been to reveal similarities and differences between semantic models of the words of the contacting languages (Lithuanian and English), influencing the choice of foreign sememes, and to reveal semantic relations of IT terms.

Various associations come into play in the process of nomination. As the thought processes of people speaking different languages are similar, it is not surprising that phenomena get similar designations in the areas of specialized lexis; the vocabulary related to the field of information technologies (IT) is not an exception. The analysis of selected terms has revealed that terminology related to the field of IT, both in Lithuanian and in English, includes many simple terms that have evolved from specific common language words, as a result of shifts in their meanings. In addition, it has been found that the majority of computer terms, in both languages, have been adopted from other subject areas, in the process of "internal borrowing" (transterminization). Such terms acquire new special semes, enabling linguists to establish the position of the concept within the 
terminological system and to define the concept as a separate semantic unit. Furthermore, the research has revealed that a smaller part of the terms have entered the IT vocabulary when special terminological meanings have been assigned to common language words (the method of secondary nomination).

The majority of the analysed words that have entered the Lithuanian IT vocabulary as a result of terminization and transterminization processes can be considered semantic loantranslations, having acquired new meanings from foreign (usually English) words, and based on "borrowed" motivation. Nonetheless, many such words can also be substantiated in Lithuanian, for their terminological meanings can be explained by central, nonterminological meanings. Thus, in the majority of cases, close associations between central meanings of specific English and Lithuanian words have stimulated the development of new terminological meanings related to information technologies. By contrast, only a relatively small number of the analysed Lithuanian terms can be considered semantic formations, having acquired their terminological meanings in the process of turning Lithuanian common language words into terms.

The analysis of IT terms and their definitions has yielded the following insight: both English and Lithuanian common words are frequently turned into terms carrying specific meanings. The study focusing on the spread of semantic formations and semantic loantranslations in computer terminology has enabled the researchers to trace a noteworthy pattern in the development of vocabulary, i.e., shifts occurring in the meanings of words. Such words turned into IT terms denote the concepts related to this specific field, and their content is revealed by definitions of their terminological meanings.

\section{SOURCES}

Dagienè, Valentina, Gintautas Grigas and Tatjana Jevsikova (eds.). 2012. Enciklopedinis kompiuterijos žodynas (Encyclopedic Dictionary of Computing). Vilnius: TEV. Available at: http://ims.mii.lt/EK\%C5\%BD/ [Accessed 15 March 2017]; (EKŽ)

Encyclopedia. The Computer Language Company Inc. Available at: http://www.pcmag. com/encyclopedia [Accessed 13 December 2019]; (PCmagE)

EuroTermBank. Available at: http://www.eurotermbank.com/default.aspx [Accessed 12 March 2017]; (ETB)

Keinys, Stasys and etc. (ed.). 2011. Dabartinès lietuviu kalbos žodynas (The Dictionary of Contemporary Lithuanian). Vilnius: Lietuvių kalbos institutas. Available at: http://dz.lki.lt [Accessed 10 March 2017]; (DLKŽ)

Naktinienè, Gertrūda, etc. (ed.). 2008. Lietuviu kalbos žodynas (Lithuanian dictionary). Vilnius: Lietuvių kalbos institutas. Available at: www.lkz.lt [Accessed 12 March 2017]; (LKŽ)

Oxford English Dictionary. Available at: http://www.oed.com/ [Accessed 10 April 2017]; (OED) 


\section{REFERENCES}

Albrecht, J. (2005). Asmenybe ir karjera. Vilnius: Naujoji matrica.

Celiešienè, V. (2016). Žodžių reikšmių keitimas kaip vienas svarbiausių kompiuterijos terminijos kūrimo būdų. Santalka: Filologija. Edukologija / Coactivity: Philology, Educology, 24(1): 45-54, http://dx.doi.org/10.3846/cpe.2016.284.

Danilenko, V. (1977). Ruskaja terminologija. Opyt lingviticheskogo opisanija. Moksva: Nauka.

Fritz, G. (1998). Historische Semantik. Stuttgart: Weima.

Gaivenytė, J. (2000). Sudètinių fizikos terminų motyvacija. Lituanistica, 3/4(43/44): 19-25.

Gaivenis, K. (2002). Lietuviu terminologija: teorijos ir tvarkybos metmenys. Vilnius: Lietuvių kalbos instituto leidykla.

Gajda, S. (1990). Wprowadzenie do teorii terminu. Opole: Wyzsza Szkola Pedagogiczna im. Powstancow Slaskich.

Gedrimas, R. (2003). J. A. Pabrèžos geografijos vadovèlio terminai. Terminologija, 10: 117-133.

Gritènienè, A. (2006). Augalu pavadinimu motyvacija šiaurès panevéžiškiu tarmèje. Vilnius: Lietuvių kalbos institutas.

Jakaitienė, E. (2010). Leksikologija: studiju knyga. Vilnius: Vilniaus universiteto leidykla.

Jakaitienè, E. (1997). Lietuvių kalbos žodžių reikšmių kitimas. Gimtoji kalba, 8: 1-4.

Jakaitienè, E. (1988). Leksine semantika: monografija. Vilnius: Mokslas.

Kaulakienè, A. (2014). Terminologija. Terminografija. Terminija. Vilnius: Technika.

Kaulakienė, Rimkutė A. (2008). Kai kurių šiuolaikinès kompiuterijos terminų mikrosistemų analizè. Santalka: Filologija. Edukologija / Coactivity: Philology, Educology, 16(4): 30-37, http://dx.doi.org/10.3846/1822-430X.2008.16.4.30-37.

Kaulakienè, A. (2001). Terminizacija: semantiniai dariniai ir vertiniai. Terminologija, 8: 28-33.

Keinys, S. (2005). Dabartiné lietuviu terminologija. Vilnius: Lietuvių kalbos instituto leidykla.

Lejczyk, W. (1998). Terminoznawstwo: przedmiot, metody, struktura. Białystok: Libra.

Lubienè, J. (2008). Grybų pavadinimų motyvacija pagal išorinius arba vidinius grybo požymius. Res humanitariae, 4: 173-191.

Naktinienè, G. (2002). Specialiosios leksikos pateikimas „Bendrinès lietuvių kalbos žodyne“. Kalbos kultūra, 75: 47-56.

Paura, M. (2014). Saqvokos kompiuteriu virusas semantinis laukas. Vilniaus universitetas, Vilnius.

Paura, M. (2008). Naujas žvilgsnis ị grèsmę, pavojų ir pažeidžiamumą. Vertimo studijos, 1: 37-44, https://doi.org/10.15388/VertStud.2008.1.10617.

Pupkis, A. (2005). Kalbos kultūros studijos. Vilnius: Gimtasis žodis.

Rudaitienè, V. (2014). Kalbų kontaktai ir lietuvių kalbos tradicija. Žmogus ir žodis, 16 (3): 111-121, http://dx.doi.org/10.15823/zz.2014.017.

Šukys, J. (2006). Kalbos kultūra visiems. Kaunas: Šviesa.

Ullmann, S. (1963/1966). Semantic universals. In Joseph H. Greenberg, ed., Universals of Language (Cambridge, Mass.: MIT Press), 217-262.

Vladarskienė, R. (2014). Naujos tarptautinių žodžių reikšmės administracinèje kalboje. Taikomoji kalbotyra, 3. 